\title{
HUBUNGAN ANTARA KURANG ENERGI KRONIS (KEK) DENGAN KEJADIAN ANEMIA, PENYAKIT INFEKSI, DAN DAYA KONSENTRASI PADA REMAJA PUTRI
}

\author{
The Relationship Between Chronic Energy Deficiency (CED) with \\ Anemia, Infection Disease, And Concentration Ability in Female \\ Adolescence \\ Tri Khayatunnisa ${ }^{1}$, Hesti Permata Sari ${ }^{1}$, Farida $^{1}$ \\ ${ }^{1}$ Program Studi Ilmu Gizi, Fakultas Ilmu-Ilmu Kesehatan, Universitas Jenderal \\ Soedirman \\ trikhay7nisa@gmail.com
}

\begin{abstract}
Chronic Energy Deficiency (CED) is one of the nutritional problems in female adolescents which is marked by the size of the Upper Arm Circumference (MUAC) $<23.5 \mathrm{~cm}$. CED problems will have an impact on the incidence of anemia, infectious diseases, and the concentration ability of female adolescents. This research aimed to knowing the relationship between CED with the incidence of anemia, infectious disease, and concentration power in female adolescents. The research method was observational analytic with cross sectional approach. The sampling technique is purposive sampling. The study was conducted on female adolescents at SMK Swagaya 1 Purwokerto through online on the questionnaires for anemia and infectious diseases using google form and for measuring the concentration ability used the grid concentration test which was made on website. Bivariate analysis using chi square test. As many as 56\% of respondents experienced KEK, 54\% of respondents had anemia, 37\% had infectious disease in the past a month, and 79\% had less concentration ability. The results of bivariate analysis showed that there was relationship between CED with the concentration ability $(p=0.036, O R=0.321)$, there was no relationship between CED with the incidence of anemia $(p=0.759)$, and infectious disease $(p=0.121)$. There is relationship between CED with the concentration ability, and there is no relationship between CED with the incidence of anemia and infectious diseases.
\end{abstract}

Keywords: anemia, concentration ability, CED, infectious diseases, female adolescents.

\begin{abstract}
ABSTRAK
Kurang Energi Kronis (KEK) merupakan salah satu masalah gizi pada remaja putri yang ditandai dengan ukuran Lingkar Lengan Atas (LILA) $<23,5 \mathrm{~cm}$. Permasalahan KEK dapat berdampak pada kejadian anemia, penyakit infeksi, serta daya konsentrasi remaja putri. Penelitian ini bertujuan untuk mengetahui hubungan antara KEK dengan kejadian anemia, penyakit infeksi, dan daya konsentrasi pada remaja putri. Metode penelitian adalah analitik observasional dengan pendekatan cross sectional. Teknik sampel yaitu purposive sampling. Penelitian dilakukan pada remaja putri di SMK Swagaya 1 Purwokerto secara online pada kuesioner kejadian anemia dan penyakit infeksi menggunakan google form serta pengukuran daya konsentrasi menggunakan grid concentration test yang dibuat di website. Analisis bivariat menggunakan uji chi square. Sebanyak 56\% responden mengalami KEK, 54\% responden mengalami
\end{abstract}


anemia, 37\% mengalami penyakit infeksi pada satu bulan terakhir, serta $79 \%$ memiliki daya konsentrasi kurang. Hasil analisis bivariat menunjukan ada hubungan antara KEK dengan daya konsentrasi $(\mathrm{p}=0,036, \mathrm{OR}=0,321)$, tidak ada hubungan antara KEK dengan kejadian anemia $(\mathrm{p}=0,759)$, dan penyakit infeksi $(\mathrm{p}=0,121)$. Ada hubungan antara KEK dengan daya konsentrasi, dan tidak ada hubungan antara KEK dengan kejadian anemia dan penyakit infeksi.

Kata Kunci: anemia, daya konsentrasi, KEK, penyakit infeksi, remaja.

\section{PENDAHULUAN}

Masa remaja atau adolescence merupakan masa terjadinya peningkatan kebutuhan zat gizi dibandingkan dengan masa anak-anak, yang apabila tidak terpenuhi dapat memunculkan berbagai masalah gizi pada remaja putri (Hardinsyah 2016).

Salah satu masalah gizi pada remaja putri yaitu kurangnya asupan makan yang dalam jangka panjang dapat menyebabkan Kurang Energi Kronis (KEK) (Almatsier 2010). Hasil penelitian Zaki et al (2017) pada remaja putri di Banyumas menunjukkan ratarata asupan zat gizi makro remaja putri dalam kategori defisit berat $(<70 \%)$. Kurang Energi Kronis (KEK) merupakan kekurangan asupan energi yang berlangsung sangat lama atau menahun, sehingga pemenuhan energi dalam tubuh kurang dari kebutuhan. Seorang perempuan mengalami KEK ditandai dengan ukuran Lingkar
Lengan Atas (LILA) $<23,5 \quad \mathrm{~cm}$ (Arisman 2009).

Kekurangan energi kronis dapat mengganggu berbagai proses metabolisme dalam tubuh, diantaranya dalam proses pertumbuhan, proses produksi tenaga, fungsi imunitas, serta terjadinya perubahan fungsi dan struktur otak (Sedioetama 2010). Salah satu dampak terganggunya fungsi proses dalam tubuh yaitu pada metabolisme energi dan simpanan zat besi. Adanya penurunan metabolisme energi yang berlangsung lama dapat mengurangi simpanan zat besi dalam tubuh (Bastian et al 2019). Hasil penelitian Pramodya (2015) menunjukkan terdapat perbedaan kadar $\mathrm{Hb}$ antara remaja putri KEK dan remaja putri tidak KEK dengan signifikansi 0,027. Penelitian Adhisti (2011) menunjukkan terdapat hubungan antara ukuran LILA $<23,5 \mathrm{~cm}$ dengan kadar $\mathrm{Hb}$ remaja putri. Selain melalui pemeriksaan kadar $\mathrm{Hb}$, anemia dapat 
J.Gipas, Mei 2021, Volume 5 Nomor 1

ISSN 2599-0152 eISSN 2599-2465

http://jos.unsoed.ac.id/index.php/jgps

diukur melalui tanda gejala yang dialami seperti mudah merasa lelah, lemas, sering mengalami pusing, dan tidak bertenaga (Suryani et al 2015). Hal tersebut dapat terjadi melalui mekanisme kegagalan hemoglobin dalam membawa oksigen ke jaringan tubuh, sehingga proses metabolisme tubuh terganggu (Hardinsyah 2016).

Kekurangan energi dalam waktu lama juga menyebabkan sistem kekebalan tubuh berkurang sehingga tubuh mudah terkena penyakit infeksi (Ertiana, 2017). Hasil penelitian Prasetyo (2011) pada tikus kekurangan energi dan protein menunjukkan adanya kerusakan pada epitel dan atropi vilus pada usus serta adanya penurunan prostaglandin sehingga antigen dapat masuk dengan mudah ke dalam tubuh. Hasil penelitian Siagian (2006) menyatakan terdapat hubungan antara status gizi dengan penyakit infeksi. Dampak lainnya dari KEK pada remaja putri yaitu menurunnya kemampuan berkonsentrasi yang terjadi berkaitan dengan penurunan simpanan zat besi. Kurangnya zat besi dapat menyebabkan jumlah oksigen dalam darah yang akan dibawa kedalam jaringan tubuh

termasuk ke otak menurun sehingga konsentrasi juga menurun (Sediaoetama, 2010). Penelitian pada remaja putri di Yogyakarta oleh Apriana et al (2016) menyatakan sebanyak 28,9\% remaja memiliki konsentrasi yang kurang. Penurunan kemampuan berkonsentrasi pada remaja putri dapat menyebabkan penurunan prestasi belajar (Pujiatun, 2014). Hasil penelitian Purnakarya (2010) yang menunjukkan bahwa kekurangan zat gizi dapat mengurangi konsentrasi hingga penurunan prestasi.

Banyaknya dampak dari KEK pada remaja putri menarik perhatian peneliti untuk mengetahui apakah terdapat hubungan antara kurang energi kronis dengan kejadian anemia, penyakit infeksi, dan daya konsentrasi remaja putri di Sekolah Menengah Kejuruan $\quad$ (SMK) $\quad$ Swagaya 1 Purwokerto. Hasil pengambilan data awal pada pengukuran LILA remaja putri di SMK Swagaya 1 Purwokerto diperoleh dari 173 siswa putri, sebanyak $56,1 \%$ siswa putri mengalami KEK, sedangkan sisanya sebanyak 43,9\% tidak mengalami KEK. Tujuan 
J.Gipas, Mei 2021, Volume 5 Nomor 1

ISSN 2599-0152 eISSN 2599-2465

http://jos.unsoed.ac.id/index.php/jgps

dari penelitian ini adalah untuk

pada pengambilan data awal, memiliki mengetahui hubungan antara kurang energi kronis dengan kejadian anemia, penyakit infeksi, dan daya konsentrasi remaja putri.

\section{METODE}

\section{Desain, Tempat, dan Waktu}

Desain penelitian ini yaitu analitik observasional dengan pendekatan cross sectional. Penelitian dilakukan di SMK Swagaya 1 Purwokerto secara online karena adanya pandemi Corona Virus Disease (Covid-19). Data uji Validitas dan Reliabilitas kuesioner diambil pada tanggal 21-24 April 2020, sedangkan data penelitian diambil pada 29 April19 Mei 2020.

\section{Jumlah dan Cara Pengambilan Sampel}

Populasi penelitian adalah seluruh siswa putri dengan populasi terjangkau hanya kelas $\mathrm{X}$ dan XII. Teknik pengambilan sampel menggunakan purposive sampling berdasarkan kriteria inklusi dan eksklusi. Kriteria inklusi diantaranya siswa putri kelas X dan XII berusia 1518 tahun, mengikuti pengukuran LILA akses terhadap internet, tidak sedang menjalankan diet khusus seperti diet penyakit serta diet ketat untuk menurunkan berat badan, tidak mengkonsumsi tablet tambah darah dalam satu bulan terakhir, dan bersedia menjadi responden. Kriteria eksklusi dalam penelitian ini yaitu sedang sakit pada saat pengambilan data dan tidak melengkapi semua data dalam kuesioner yang diberikan. Hasil pengambilan data diperoleh sampel penelitian sebanyak 100 dari 173 berdasarkan kriteria inklusi dan tidak terkena kriteria eksklusi.

\section{Cara Pengumpulan Data}

Alur pengumpulan data yaitu dilakukan penelitian pra-survey untuk mengukur LILA siswa putri (sebelum pandemi Covid-19). Setelah adanya himbauan penelitian harus dilakukan secara online, peneliti meminta data nomor handphone semua siswa putri. Kemudian penelitian dilanjutkan secara online dengan membuat grup whatsapp kemudian membagi dua link: link pertama berisi kuesioner kejadian anemia dan penyakit infeksi, sedangkan 
J.Gipas, Mei 2021, Volume 5 Nomor 1

ISSN 2599-0152 eISSN 2599-2465

http://jos.unsoed.ac.id/index.php/jgps

link kedua berisi tes konsentrasi. Selain itu, para responden juga dihubungi satu-persatu terkait pengisian link. . Variabel bebas yaitu status gizi Kurang Energi Kronik (KEK), sedangkan variabel terikat yaitu kejadian anemia, penyakit infeksi, dan daya konsentrasi.

\section{Instrumen Penelitian}

Instrumen penelitian yang digunakan yaitu metline dengan ketelitian $0,1 \mathrm{~cm}$ untuk mengukur LILA oleh enumerator, google form berisi data diri responden, kuesioner tanda gejala anemia, serta kuesioner penyakit infeksi: diare, batuk/pilek/flu, dan demam, serta pengembangan website berisi grid concentration test untuk mengukur daya konsentrasi. Uji validitas dan realibilitas telah dilakukan pada kuesioner kejadian anemia dan kuesione penyakit infeksi sebelum pengambilan data penelitian.

Analisis Data
Analisis data diawali dengan analisis univariat meliputi uji deskriptif karakteristik usia responden, dan uji deskriptif pada data variabel yang diteliti. Uji normalitas menggunakan uji Kolmogorov Smirnov untuk menentukan pengkategorian pada variabel kejadian anemia dan penyakit infeksi. Kejadian anemia berdistribusi normal sehingga kategori mengunakan nilai mean, sedangkan variabel penyakit infeksi berdistribusi tidak normal sehingga kategori menggunakan nilai median. Tahap terakhir analisis data yaitu analisis bivariat menggunakan uji Chi Square dengan derajat kepercayaan 95\% $(\alpha=0,05)$.

\section{HASIL DAN PEMBAHASAN}

\section{Karakteristik Responden}

Responden pada penelitian ini merupakan remaja putri masa pertengahan. Sebaran usia responden disajikan pada tabel 1 dibawah ini. 
Tabel 1. Sebaran Usia Responden

\begin{tabular}{cccc}
\hline Karakteristik & n & \% \\
\hline Usia (Tahun) & & \\
& 15 & 14 & 14 \\
& 16 & 17 & 27 \\
17 & 27 & 42 \\
\hline 18 & 42 & $\mathbf{1 0 0}$ \\
\hline Total & $\mathbf{1 0 0}$ & Sumber: Data primer terolah, 2020
\end{tabular}

Responden merupakan remaja putri yang tersebar dari usia 15-18 tahun dengan jumlah terbanyak berusia 18 tahun (42\%). Masa remaja pada rentang usia 15 hingga 18 tahun merupakan masa remaja pertengahan (Desmita 2013). Menurut Wulandari (2014) remaja merupakan masa yang penuh dengan storm dan stress atau disebut dengan masa pubertas (Wulandari 2014). Pada masa ini terjadi perkembangan fisik maupun psikis yang cepat dibandingkan dengan masa sebelumnya. Menurut Santrock (2011) masa remaja merupakan masa perkembangan dengan ciri sering mengalami masa krisis dan ambigu sehingga selalu tidak stabil, mengalami konflik sikap dan perilaku, dan emosional.

\section{Distribusi Frekuensi Variabel yang} Diteliti

Sebaran distribusi frekuensi dari variabel yang diteliti disajikan pada tabel berikut.

Tabel 2. Distribusi Frekuensi Variabel yang Diteliti

\begin{tabular}{lcc}
\hline \multicolumn{1}{c}{ Variabel } & n & \% \\
\hline Status Gizi & & 56 \\
KEK & 56 & 44 \\
Tidak KEK & 44 & \\
\hline Kejadian Anemia & 54 & 54 \\
Anemia & 46 & 46 \\
Tidak Anemia & & 37 \\
\hline Penyakit Infeksi & 37 & 63 \\
$\quad$ Mengalami penyakit infeksi satu bulan terakhir & 63 & 79 \\
Tidak mengalami penyakit infeksi satu bulan terakhir & & 21 \\
\hline Daya Konsentrasi & 79 & $\mathbf{1 0 0}$ \\
$\quad$ Kurang & 21 & $\mathbf{1 0 0}$ \\
Baik & Sumber: Data primer terolah, 2020
\end{tabular}


J.Gipas, Mei 2021, Volume 5 Nomor 1

ISSN 2599-0152 eISSN 2599-2465

http://jos.unsoed.ac.id/index.php/igps

Berdasarkan analisis distribusi frekuensi pada variabel status gizi responden berdasarkan indikator LILA diperoleh sebanyak 56\% responden mengalami KEK. Kurang energi kronis ditandai dengan ukuran LILA $<23,5$ $\mathrm{cm}$. Pengukuran LILA merupakan pengukuran yang mudah untuk mendeteksi awal suatu kelompok beresiko KEK atau tidak. Lingkar lengan atas merupakan indikator yang dapat menentukan status gizi pada masa lampau dengan yang menggambarkan keadaan jaringan otot dan lapisan lemak dibawah kulit (Ariyani et al 2012).

Variabel lainnya yaitu kejadian anemia yang diperoleh sebanyak 54\% responden mengalami anemia menurut tanda dan gejala yang dialaminya, seperti telapak tangan, kelopak mata, serta wajah yang terlihat pucat, merasa lemas, pusing berkunang-kunang, lesu, letih, serta sering merasa kantuk walaupun jam tidur sudah tepat. Selain itu, terdapat $37 \%$ reponden mengalami penyakit infeksi pada satu bulan terakhir. Berdasarkan hasil penelitian, penyakit infeksi yang paling banyak dialami responden pada stau bulan terakhir yaitu batuk/pilek/flu (21\%). Batuk/pilek/flu merupakan sekumpulan gejala influenza. Influenza merupakan penyakit Infeksi Saluran Pernafasan Akut (ISPA) yang diakibatkan oleh virus dan merupakan penyakit yang dapat sembuh sendiri (self limiting disease) (Horwood 2002). Kemudian hasil pengukuran daya konsentrasi menggunakan grid concentration test menunjukkan sebanyak 79\% responden memiliki daya konsentrasi yang kurang. Kategori daya konsentrasi yang kurang merupakan kombinasi dari kategori kurang dan sangat kurang, sedangkan kategori daya konsentrasi baik merupakan kombinasi dari kategori cukup, baik, dan sangat baik.

\section{Hubungan Antara Kurang Energi Kronis (KEK) dengan Kejadian Anemia}

Hubungan antara KEK dengan kejadian anemia disajikan pada tabel 3 dibawah ini: 
Tabel 3. Uji Chi Square Antara Status Gizi dengan Kejadian Anemia

\begin{tabular}{|c|c|c|c|c|c|c|c|c|}
\hline & & \multicolumn{4}{|c|}{ Kejadian Anemia } & \multirow{2}{*}{\multicolumn{2}{|c|}{ Total }} & \multirow{3}{*}{ p } \\
\hline & & \multicolumn{2}{|c|}{ Anemia } & \multicolumn{2}{|c|}{ Tidak anemia } & & & \\
\hline & & $\mathrm{n}$ & $\%$ & $\mathrm{n}$ & $\%$ & $\mathrm{n}$ & $\%$ & \\
\hline Status & KEK & 31 & 55,4 & 25 & 44,6 & 56 & 100 & \\
\hline Gizi & Tidak KEK & 23 & 52,3 & 21 & 47,7 & 44 & 100 & 0,759 \\
\hline Total & & 54 & 54 & 46 & 46 & 100 & 100 & \\
\hline
\end{tabular}

Berdasarkan analisis bivariat antara KEK dengan kejadian anemia, diperoleh nilai $\mathrm{p}=0,759$ yang dapat disimpulkan bahwa tidak ada hubungan antara KEK dengan kejadian anemia ( $p>0,05 /$ Ho diterima). Hasil penelitian ini tidak sesuai dengan Kaimudin (2017) yang menyatakan bahwa terdapat hubungan antara status gizi dengan kejadian anemia pada remaja putri. Namun penelitian ini sesuai dengan hasil penelitian Mariana (2013), Indartanti (2014), Indriani (2017), dan Adiyani et al (2018) yang menunjukkan tidak terdapat hubungan antara status gizi dengan kejadian anemia remaja putri.

Penelitian ini menyatakan tidak adanya hubungan kejadian KEK dengan kejadian anemia dapat dipengaruhi oleh pengukuran kejadian anemia melalui tanda gejala anemia dapat bersifat subjektif, sedangkan media yang lebih objektif dalam menilai kejadian anemia tidak dilakukan dalam penelitian ini yaitu pengecekan kadar hemoglobin. Selain itu, terdapat banyak faktor yang meyebabkan kejadian anemia selain KEK, diantaranya tingkat konsumsi zat gizi, dan pola asupan makanan, dan kebiasaan sarapan pagi pada responden (Indriani 2017), diet yang cenderung membatasi asupan makanan (Miller et al 2009), konsumsi zat besi (Adiyani et al 2018), konsumsi makanan tinggi serat, tanin, dan fitat (Adriyana 2010), serta dari faktor sosial ekonomi, akses layanan kesehatan, serta karakteristik biologis remaja putri (Rivadeneira et al 2020).

\section{Hubungan Antara Kurang Energi Kronis (KEK) dengan Penyakit Infeksi}


Hubungan antara KEK dengan peyakit

infeksi disajikan pada tabel 4 dibawah

ini:

Tabel 4. Uji Chi Square Antara Status Gizi dengan Penyakit Infeksi

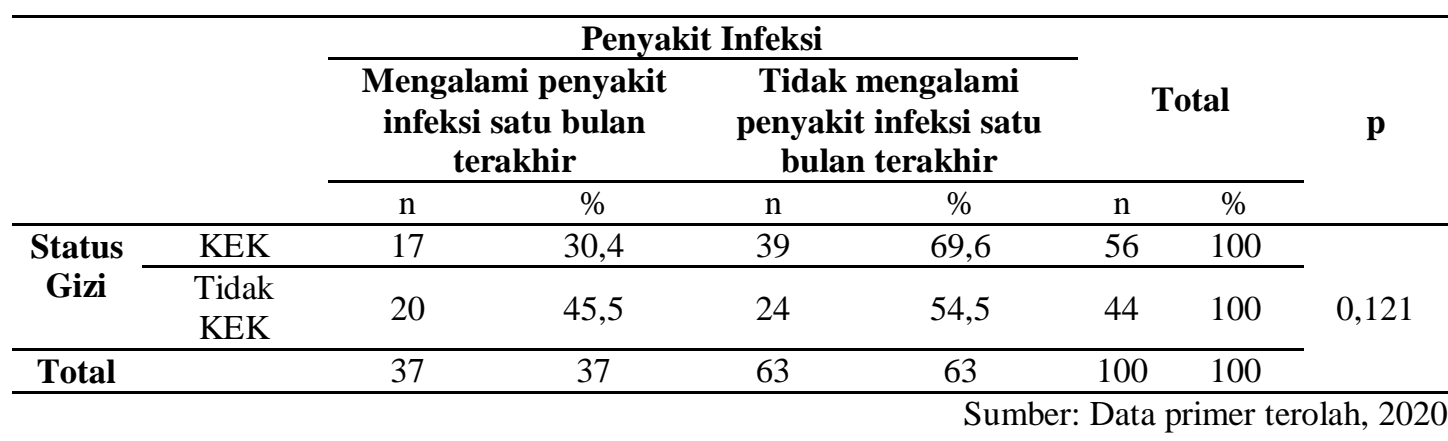

Berdasarkan analisis bivariat antara KEK dengan kejadian penyakit infeksi, diperoleh nilai $\mathrm{p}=0,121$ ( $p>0,05 /$ Ho diterima) sehingga dapat disimpulkan tidak ada hubungan antara KEK dengan penyakit infeksi. Penyakit infeksi yang diteliti dalam penelitian ini yaitu diare, batuk/pilek/flu, dan demam. Diare termasuk dalam water borne disease atau penyakit dengan penyebaran mikroorganisme patogen ditularkan melalui air yang terkontaminasi yang ditandai oleh terjadinya perubahan konsistensi tinja menjadi lebih cair dengan frekuensi buang air besar lebih sering dari biasanya (lebih dari 3 kali dalam satu hari) (Prawati 2019). Flu merupakan penyakit yang mudah menular dengan gejala hidung berair (rhinorrhea), hidung tersumbat, tenggorokan sakit, serta sakit kepala. Influenza merupakan disease burden karena dapat mempengaruhi komunitas melalui bersin, batuk, maupun berbincangbincang dengan penderita. (Dhamayanti, 2012).

Hasil penelitian ini tidak sesuai dengan mekanisme hubungan timbal balik antara status gizi dengan penyakit infeksi dimana kekurangan gizi mengakibatkan infeksi dan sebaliknya terjadinya infeksi dapat menyebabkan kekurangan gizi (Walson 2018). Penelitian ini menyatakan tidak adanya hubungan antara kejadian KEK dengan kejadian penyakit infeksi dapat disebabkan pada penelitian ini tidak 
J.Gipas, Mei 2021, Volume 5 Nomor 1

ISSN 2599-0152 eISSN 2599-2465

http://jos.unsoed.ac.id/index.php/igps

mencakup semua tanda dan gejala

penyakit infeksi selain kejaidan KEK terjadinya penyakit infeksi, seperti diantaranya kebersihan lingkungan lidah kotor, tremor, sesak nafas, tenggorokan sakit saat menelan, dan mendengkur saat tidur, serta jenis penyakit ISPA lainnya seperti radang amandel dan radang tenggorokan. Selain itu, tidak mudah untuk mendiagnosis adanya penyakit infeksi, terkadang seseorang tidak merasakan bahwa tubuhnya sedang terinfeksi baik virus maupun bakteri (Mustaqof 2015).

Faktor lainnya yang mempengaruhi (Rahman et al 2016), adanya higiene sanitasi yang buruk, kontaminasi dalam pangan dan air, serta pengerahuan gizi yang kurang (Siagian 2006).

Hubungan Antara Kurang Energi Kronis (KEK) dengan Daya Konsentrasi

Hubungan antara KEK dengan daya konsentrasi disajikan pada tabel 5 dibawah ini:

Tabel 5. Uji Chi Square Antara Status Gizi dengan Daya Konsentrasi

\begin{tabular}{|c|c|c|c|c|c|c|c|c|c|}
\hline & & \multicolumn{4}{|c|}{ Daya Konsentrasi } & \multirow{2}{*}{\multicolumn{2}{|c|}{ Total }} & \multirow{3}{*}{ p } & \multirow{3}{*}{ OR } \\
\hline & & \multicolumn{2}{|c|}{ Kurang } & \multicolumn{2}{|c|}{ Baik } & & & & \\
\hline & & $\mathrm{N}$ & $\%$ & $\mathrm{n}$ & $\%$ & $\mathrm{n}$ & $\%$ & & \\
\hline Status & KEK & 40 & 71,4 & 16 & 28,6 & 56 & 100 & & \\
\hline Gizi & Tidak KEK & 39 & 88,6 & 5 & 11,4 & 44 & 100 & 0,036 & 0,321 \\
\hline Total & & 79 & 79 & 21 & 21 & 100 & 100 & & \\
\hline
\end{tabular}

Pengukuran daya konsentrasi dalam penelitian ini menggunakan grid concentration test berupa tampilan 100 kotak (10x10 kotak) yang berisi angka acak. Responden diminta mengurutkan angka acak tersebut dalam 1 menit. Semakin banyak angka yang berhasil diurutkan maka semakin baik daya konsentrasinya. Hasil analisis bivariat antara KEK dengan daya konsentrasi diperoleh nilai $\mathrm{p}=0,036 \quad(\mathrm{p}<0,05 / \mathrm{Ho}$ ditolak) sehingga dapat disimpulkan ada hubungan antara KEK dengan daya konsentrasi remaja putri. Selain itu, diperoleh nilai OR sebesar 0,321 $(\mathrm{OR}<1)$. Nilai $\mathrm{OR}$ kurang dari 1 memiliki arti mengurangi resiko atau berasosiasi negatif dimana pajanan dapat melindungi hasil yang sedang diteliti (Riwidikdo 2012). Nilai OR pada penelitian ini berarti remaja putri yang tidak KEK mengurangi risiko 
J.Gipas, Mei 2021, Volume 5 Nomor 1

ISSN 2599-0152 eISSN 2599-2465

http://jos.unsoed.ac.id/index.php/jgps

terjadinya penurunan daya konsentrasi sebesar $32,1 \%$.

Daya konsentrasi merupakan kemampuan untuk memfokuskan perhatian pada keadaan dimana kesadaran tertuju pada suatu objek dalam waktu tertentu (Maksum 2011). Baik buruknya daya konsentrasi pada remaja putri dapat berdampak pada konsentrasi belajar yang dapat mempengaruhi hasil belajar maupun prestasi. Hasil penelitian Nurwijayanti (2018) menunjukkan terdapat hubungan antara status gizi dengan prestasi belajar remaja putri. Selain itu penelitian Chinyoka menunjukan seseorang yang mengalami kekurangan gizi berdampak negatif pada perkembangan kognitif dan prestasi belajar.

Mekanisme terjadinya KEK dapat mempengaruhi daya konsentrasi yaitu kekurangan zat gizi kronis pada masa lampau akan berdampak pada perubahan metabolisme di otak. Otak tidak dapat bekerja dengan baik jika tidak mendapat asupan gizi, sehingga kekurangan gizi pada kurun waktu yang lama dapat mengganggu kemampuan kognitif. Kemampuan kognitif yang terganggu menyebabkan anak atau remaja tidak dapat fokus dan berkonsentrasi pada kegiatan pembelajaran, sehingga prestasi belajar menurun (Wedu et al 2018). Kemampuan kognitif yang terganggu terjadi karena perubahan struktur pada otak. Penelitian pada tikus kekurangan gizi menunjukkan walaupun tikus membaik setelah diberi makan, namun perubahan struktur otak dianggap permanen, yaitu menurunnya jumlah mielin dan dendrit kortikal yang mengakibatkan menurunnya kecepatan otak dalam menerima dan memproses informasi (Hodgin 2009). Selain itu, terjadinya KEK berpengaruh pada kurangnya glukosa dalam tubuh terutama otak. Menurut Almatsier (2010) glukosa merupakan sumber energi utama bagi otak. Kurangnya kadar glukosa dalam darah berdampak negatif pada konsentrasi (Larega 2015).

\section{Program Pemberian TTD Remaja oleh Pemerintah}

Pemerintah memiliki program pemberian suplementasi tablet tambah darah sebagai sumber zat besi untuk 
J.Gipas, Mei 2021, Volume 5 Nomor 1

ISSN 2599-0152 eISSN 2599-2465

http://jos.unsoed.ac.id/index.php/jgps

para remaja. Namun dalam pemantauan secara langsung dalam

pelaksanaannya diperlukan

pengerjaan kuesioner dan tingkat

pemantauan dan evaluasi

konsentrasi.

efektifitasnya. Hasil penelitian Hidayat

(2020) menunjukkan tingkat kepatuhan

siswa terhadap program sebanyak $76 \%$

dan sebanyak $77,5 \%$ telah sadar untuk

mengkonsumsi TTD. Selain itu, hasil

penelitian Quraini (2020) menunjukkan

hanya $57 \%$ responden remaja putri

yang memiliki niat untuk

mengkonsumsi TTD. Hal tersebut

selaras dengan hasil penelitian iniyang

menunjukkan masih banyaknya remaja

putri yang mengalami anemia

(berdasarkan tanda gejala yang

dialami). Apriningsih (2019)

menyimpulkan selain peran pihak

sekolah, orang tua siswi/remaja putri

perlu terlibat dalam program

suplementasizat besi remaja putri.

\section{Keterbatasan Penelitian}

Kurangnya data untuk analisis univariat, seperti kondisi sosial ekonomi keluarga dan tingkat pengetahuan responden. Tidak dilakukan pengecekan kadar hemoglobin dalam menentukan kejadian anemia, serta tidak dilakukan 
J.Gipas, Mei 2021, Volume 5 Nomor 1 ISSN 2599-0152 eISSN 2599-2465 http://jos.unsoed.ac.id/index.php/jgps

\section{DAFTAR PUSTAKA}

Adhisti, Anindya Putri. 2011, 'Hubungan Status Antropometri dan Asupan Gizi dengan Kadar $\mathrm{Hb}$ dan Ferritin Remaja Putri', Skripsi, Fakultas Kedokteran Universitas

Diponegoro, Semarang.

Adiyani, Khalilah., Farida Heriyani, dan Lena Rosida, 2018, 'Hubungan Status Gizi dengan Kejadian Anemia pada Remaja Putri di SMA PGRI 4 Banjarmasin', Homeostatis, Vol. 1, No. 1:1-7. Adriyana, 2010, 'Faktor-Faktor yang Berhubungan dengan Kejadian Anemia Remaja Putri di Madrasah Aliyah Negeri 2 Bogor', Skripsi, Fakultas Kedokteran dan Ilmu Kesehatan Universitas Islam Negri Syarif Hidayatullah, Jakarta.

Almatsier, Sunita, 2010, Prinsip Dasar Ilmu Gizi, PT Gramedia Pustaka Utama, Jakarta.

Apriningsih, dkk. 2019, 'Peranan Orang Tua dalam Meningkatkan Kepatuhan Siswi Minum Tablet Zat Besi Folat di Kota Depok', Journal of The Indonesian Nutrition Association, 42(2):71-82
Arisman 2010, Gizi Dalam Daur

Kehidupan, EGC, Jakarta.

Apriana, Wieke et al, 2016, 'Relationship Between Physical Activity and Concentration of Study of Teenagers in Yogyakarta, Indonesia', Pakistan Journal of Nutrition, 15(3): 211-216

Ariyani, Diny Eva., Endang L. Achadi, dan Anies Irawati, 2012, 'Validitas Lingkar Lengan Atas

Mendeteksi Risiko Kekurangan Energi Kronis pada Wanita Indonesia', Jurnal Kesehatan Masyarakat Nasional', Vol. 7, No. 2.

Bastian, Thomas W., William C. von Hohenberg, Michael K. Georgieff, dan Lorene M. Lanier, 2019, 'Chronic Energy Depletion due to Iron Deficiency Impairs Dendritic

Mitochondrial Motility during Hippocampal Neuron Development', The Journal of Neuroscience, 39(5):802-813.

Chinyoka, K., 2014, 'Impact of Poor Nutrition on The Academic Performance of Grade Seven Learnes: A Case of Zimbabwe', International Journal of Learning and Development, Vol. 4, No. 3, 73-84. 
J.Gipas, Mei 2021, Volume 5 Nomor 1 ISSN 2599-0152 eISSN 2599-2465 http://jos.unsoed.ac.id/index.php/igps

Desmita 2013, Psikologi

Perkembangan, PT Remanja

Rosdakarya, Bandung.

Ertiana, Dwi., dan Putri Suryani Wahyuningsih 2019, 'Asupan Makan dengan Kejadian KEK pada Remaja Putri di SMAN 2 Pare Kabupaten Kediri', Jurnal Gizi kh. 1(2): 102-109.

Hardinsyah dan I Dewa Nyoman Supariasa 2016, Ilmu Gizi Teori dan Aplikasi, EGC, Jakarta.

Hidayat, R., Effendi, dan Alfon Vekoli Laia 2020, 'Pelaksanaan Program Pemberian Tablet Tambah Darah Untuk Meningkatkan Kesadaran Perilaku Hidup Bersih dan

Sehat Siswi SMA Negeri', JAMP Jurnal Administrasi dan Manajemen Pendidikan, Vol. 3, No. 2, $152-$ 159

Hodgin GE, 2009, 'Nutrition and Academic Achievement', Department of Nutrition and Dietetics.

Horwood, F., J Macfarlane 2002, 'Pneumococcal and Influenza Vaccination: Current Situation and Future Prospects', Thorax, 57:ii24-ii30. Indartanti, Dea., dan Apoina Kartini, 2014, 'Hubungan Status Gizi dengan
Kejadian Anemia pada Remaja Putri', Journal of Nutrition College, Vol. 3, No. 2, 33- 39.

Indriani, Aisyah, 2017, 'Hubungan Status Gizi dengan Kejadian Anemia pada Remaja Putri di SMAN 1 Kasihan', Naskah Publikasi, Fakultas Ilmu Kesehatan Universitas 'Aisyiyah, Yogyakarta.

Kaimudin, Nur Ia., Hariati Lestari, dan Jusniar Rusli Afa, 2017, 'Skrining dan Determinan Kejadian Anemia pada Remaja Putri SMA Negeri 3 Kendari Tahun 2017',

JIMKESMAS Jurnal Ilmiah Mahasiswa Kesehatan Masyarakat, Vol. 2, No. 6, ISSN 250-731X.

Larega, Tanika Sania Putri, 2015, 'Effect of Breakfast on The Level of Concentration in Adolescents', $J$ Majority Artikel Riview, Vol. 4, No. 2.

Maksum, Ali, 2011, Psikologi Olahraga teori dan Aplikasi, Unesa University Press, Surabaya.

Mariana, Wina., dan Nur Khafidhoh, 2013, 'Hubungan Status Gizi dengan Kejadian Anemia pada Remaja Putri di SMK Swadaya Wilayah Kerja Puskesmas Karangdoro Kota Semarang Tahun 2013', Jurnal 
J.Gipas, Mei 2021, Volume 5 Nomor 1 ISSN 2599-0152 eISSN 2599-2465

http://jos.unsoed.ac.id/index.php/jgps

Kebidanan, Vol. 2, No. 4.

Kejadian Kurang Energi Kronis

ISSN.2089-7669.

Miller, Heather A Eicher, April C

Mason, dan Connie M Weave ,2009,

'Food Insecurity is Associated with

Iron Deficiency Anemia in US

Adolescents', Am J Clin Nutr.

90:1358-71.

Mustaqof, Ahmad Aniq Noor.,

Wiharto, dan Esti Suryani, 2015,

'Sistem Pakar untuk Mendiagnosis

Penyakit Infeksi Menggunakan

Forward Chaining', Jurnal Itsmart,

Vol. 4, No. 1.

Nurwijayanti, 2018,'Pola Makan,

Kebiasaan Sarapan, dan Status Gizi

Berhubungan dengan Prestasi Belajar

siswa SMK di Kota Kediri', Jurnal

Care, Vol. 6(1).

Pramodya W, Juwita., M. Zen

Rahfiludin, dan Siti Fatimah P., 2015,'Perbedaan Aktivitas Fisik,

Kadar Hb, dan Kesegaran Jasmani

(Studi pada Siswi KEK dan

Tidak KEK di SMA N 1 Grogol

Kabupaten Kediri)',Jurnal Kesehatan

Masyarakat, Vol. 3, No. 1,

ISSN: 2356-3346).

Pujiatun, Tri, 2014, Hubungan Tingkat

Konsumsi Energi dan Protein dengan

(KEK) pada Siswa Putri di SMA Muhammadiyah 6 Surakarta, NASKAH PUBLIKASI, Univeristas Muhammadiyah Surakarta, Surakarta.

Purnakarya, 2010, Pengaruh Zat Gizi pada Prestasi, Jakarta.

Quraini, DF., Farida Wahyu Ningtyias, dan Ninna Rohmawati 2020, 'Perilaku Kepatuhan Konsumsu Tablet Tambah DarahRemaja Putri di Jember, Indonesia', Jurnal Promkes: The Indonesian Journal of Health Promotion and Health Education, Vol. 8 No. 2, 154-162

Rahman, Handoto Fatkhur, et al., 2016, 'Faktor-Faktor yang Berhubungan dengan Kejadian Diare di Desa Solor Kecamatan Cermee Bondowoso', NurseLine Journal, Vol. 1, No. 1, ISSN 2540-7973.

Rivadeneira, Maria F. et al, 2020, 'A Multi-causal Model for Chronic Malnutrition and Anemia in a Population of Rural Coastal Children in Ecuador, Maternal and Child Health Journal, 24:472-482.

Riwidikdo, Handoko, 2012, Statistik Kesehatan, Nuha Medika, Yogyakarta. 
J.Gipas, Mei 2021, Volume 5 Nomor 1 ISSN 2599-0152 eISSN 2599-2465 http://jos.unsoed.ac.id/index.php/igps

Santrock, John W., 2011,

School Students Achievement: A Perkembangan Anak Edisi 7 Jilid 2 Massive Prospective Cohort terjemahan: Sarah Genis B, Erlangga, Jakarta.

Sediaoetama, A., 2010, Ilmu Gizi untuk Mahasiswa dan Profesi, Dian Rakyat, Jakarta.

Siagian, Albiner 2006, 'Gizi, Imunitas, dan Penyakit Infeksi', Info Kesehatan Masyarakat, Universitas Sumatera Utara,Vol. X, No. 2.

Suryani,Desri., Riska Hafiani, dan Rinsesti Junita, 2015, Analisis Pola Makan dan Anemia Gizi Besi pada Remaja Putri di Kota Bengkulu, Jurnal Kesehatan Masyarakat Andalas, 10(1)11-18.

Walson, Judd L., dan James A. Barkley, 2018, 'The Impact of Malnutrition on Childhood Infections', Riview, Wolters Kluwer Health Inc., Vol. 31, No. 3 .

Wedu, Zefanya Ricky., Eti Poncorini Pamungkasari, dan Sapja Anantanyu, 2018, 'Nutrition Status Affects High n VII, Purwokerto. 